\title{
The Impact of Donor Support to Basic Education in Ghana since the 1987 Education Sector Reforms
}

\author{
Sulemana Adams Achanso \\ Dept. of Development Education Studies \\ Faculty of Education \\ University for Development Studies \\ Tamale, Ghana \\ Email:dr.saachanso@uds.edu.gh \\ DOI:http://dx.doi.org/10.4314/gjds.v10i1\&2.6
}

\begin{abstract}
This paper examines the impact of donor support to Ghana's Basic Education sector since the 1987 Education Sector Reforms. It explores the extents to which donor support had contributed to the mitigating the challenges of basic education in Ghana in order to determine what remains. The paper draws on extensive literature sources and in-depth interviews with donor agencies and policymakers that are connected to the provision of Basic Education in Ghana. The data was collected for a doctoral thesis between 2006 and 2011. The paper argues that while donor support had sought to contribute to the resolution of many of the challenges facing Ghana's Basic Education sector, many of the challenges remain. It found that there have been positive impacts such as gender parity at the basic level, improvements enrolment, attainment and complete rates yet others such as management inefficiency, poor motivation and teacher commitment, within sector challenges, weak supervision and ineffective sector coordination remain. Hence, it has been suggested that much more collaboration between donors and the Ghanaian government is needed to effectively tackle the persistent Basic Education sector challenges.
\end{abstract}

KEY WORDS: Basic Education, Donor Support, Education Reforms, structural adjustments, Budget

\section{Introduction}

This paper explores the extent to which Ghana's basic education system has benefitted key external agencies, including the International Monetary Fund, the World Bank, the Department for International Development, the United States Agency for International Development, and a host of bilateral donor agencies, since 1987, when the Ghanaian government launched an education reform programme as part of a wider structural adjustment programme to reconstruct the country's education system following years of 
decline. Basic education (Ages 4-12) was selected for this study because the literature and the field data in the study suggested that the sector had received more external support than any other social sector - including other sectors within the education system since the implementation of the reform programme.

The analysis is based on data collected between 2006 and 2011 for a doctoral dissertation study. It was a qualitative descriptive study that drew data mainly from existing literature, statistical databases and empirical studies.

The paper provides an overview of the state of basic education in Ghana by the mid1980 os that necessitated the introduction of the reform programme. This is followed by an evaluation of the contribution of key external donor agencies' support to the programme and its impact on the provision of basic education in the country. The emphasis on donor sources is because, at the time that the Ghanaian economy was in an ailing state and could not meet the development requirements of many of the sectors especially the severely challenged education sector, donor agencies such as the IMF and the World Bank stepped in and made significant contributions toward the closing of the funding gap. The analysis shows that in spite of the improvements funding to the education sector and the programme of reforms to improve education development, many challenges remain. It acknowledges the improvements in educational enrolments, attainments and achievement, several challenges remain that require further attention in order for the goals of the reforms to be realized.

\section{The State of Basic Education in Ghana by the Mid 1980S}

By the early 1980s, the education system in Ghana was in severe crisis (Kadingdi, 2004), as the country's economic downturn had adversely affected educational spending. Thus, the budget for education had been slashed from $6.4 \%$ of GDP in 1976 to $1.4 \%$ of GDP in 1983 (Kadingdi, 2004; Thompson and Casely-Hayford, 2007). This inadequate investment resulted in the deterioration of educational infrastructure and a shortage of teaching and learning materials, as well as an exodus of trained teachers and their replacement by untrained staff (Ayamdoo et al.; 2006; World Bank, 2004). Ahadzie (2000) has estimated that, by 1983, about half of all trained teachers in Ghana had left the country. Cuts in the education sector budget also contributed to poor motivation among other education sector workers, including administrators, which led to a reduction in the quality of the management of the education sector (Kadingdi, 2004).

At the same time that the education sector came under pressure, the incomes of parents were also falling, which led to lower enrolment and retention as parents could not meet the costs of their children's education (Oduro, 2000). As a result, the General Enrolment Ratio in Primary schools declined from $80 \%$ in 1980 to $70 \%$ by 1986 (Kadingdi, 2004). The then PNDC Secretary of Education, Ben Abdullah, decried the impact of the severity of the political and the economic downturns on Ghana's education system as follows: "Over the past decade, there has been a harsh deterioration in the quality of education at all levels. 
There has been a virtual collapse of physical infrastructure in the provision of buildings, equipment, materials, teaching aids, etc..." (Abdallah, 1986:1 cited in Kadingdi, 2004).

It was against this background that the 1987 Education Reform Programme was introduced by the Ghanaian government as part of the International Monetary Fund and the World Bank sponsored Economic Recovery and Structural Adjustment programmes, leading to a closer and long term involvement of bilateral and multilateral donor agencies in the development of basic education in Ghana (World Bank, 2004; Thompson and CaselyHayford, 2007). The reforms were also intended to consolidate the outcomes of the 1974 Reforms of the previous decade, which introduced considerable reforms in the structure and content of education (Kadingdi, 2004).

The main aim of the 1987 Education Reform Programme was to secure the necessary resources to expand access and improve the quality of educational delivery and outcomes (MoE, 1988). The reform was also aimed to improve educational management, including planning and monitoring. In addition, the programme was to improve student performance through quality teaching by increasing the number of trained teachers. Finally, there was a shift from a predominantly academic focus of the pre-tertiary curriculum towards more technical and vocational education and training to address concerns that pre-tertiary education was not preparing students adequately for the labour market.

Between 1987 and 2008, additional policy reforms were made to address challenges emanating from the implementation of the 1987 Reforms and to consolidate success chalked under the reforms. These are illustrated in Table 1 below.

Table 1: Key Education Policy Recommendations and Reforms: 1987-2008

\begin{tabular}{|l|l|}
\hline Date/Event & Commentary \\
\hline 1987 Education Reform Programme & $\begin{array}{l}\text { Introduced 6 + 3+3: primary + JSS + Senior } \\
\text { Secondary School. Attempted to arrest decline of the } \\
\text { whole system. }\end{array}$ \\
\hline $\begin{array}{l}1992 \text { Constitutional Provision on } \\
\text { Basic Education }\end{array}$ & $\begin{array}{l}\text { Free, Compulsory, Universal Basic Education (FCUBE) a } \\
\text { constitutional right for all children. }\end{array}$ \\
\hline 1995 Implementation of the FCUBE & $\begin{array}{l}\text { Pleas by Minister to donors to prioritise support for basic } \\
\text { education and to fund through a "basket approach. }\end{array}$ \\
\hline 2003 Education Sector Plan (ESP) & $\begin{array}{l}\text { First comprehensive sector plan, 20o3-2015, to } \\
\text { coordinate education sector programmes. } \\
\text { Development supported by UNICEF and DFID. }\end{array}$ \\
\hline 2005 Grant capitalisation scheme & $\begin{array}{l}\text { Removes fees from basic education, replacing with a per } \\
\text { capita grant going to each basic school. }\end{array}$ \\
\hline
\end{tabular}




\begin{tabular}{|l|l|}
\hline 2007 The New Education Reform & $\begin{array}{l}\text { Introduced two years of kindergarten as part of Basic } \\
\text { Education }\end{array}$ \\
\hline $\begin{array}{l}2008 \text { (November) Education Act } \\
\text { passed }\end{array}$ & $\begin{array}{l}\text { Introduced independent inspectorate, curriculum and } \\
\text { assessment bodies. }\end{array}$ \\
\hline
\end{tabular}

Source: Allsop, Attah and Cammack (2009)

\section{Donor Funding for Basic Education since 1987}

Government funding of the 1987 Reform Programme was supplemented by major external donor agencies as illustrated in Tables 2 below.

Table 2: Major Donor Funding for Basic Education under the 1987 Reform Programme

\begin{tabular}{|c|c|c|c|c|}
\hline Name of Project & Donor & Effective Date & $\begin{array}{l}\text { Amount in US } \\
\text { \$million }\end{array}$ & $\begin{array}{l}\text { Beneficiary Sub- } \\
\text { Sector }\end{array}$ \\
\hline $\begin{array}{l}\text { Education Sector } \\
\text { Adjustment Credit } \\
\text { (EdSAC I) }\end{array}$ & IDA & 1989 & 34.5 & $\begin{array}{l}\text { Pre-university } \\
\text { Education }\end{array}$ \\
\hline $\begin{array}{l}\text { Education Sector } \\
\text { Adjustment Credit } \\
(\text { EdSAC II) }\end{array}$ & IDA & 1990 & 50.0 & $\begin{array}{l}\text { Pre-university } \\
\text { Education }\end{array}$ \\
\hline $\begin{array}{l}\text { Primary School } \\
\text { Development } \\
\text { Project }\end{array}$ & IDA & $1993-1998$ & 82.96 & Basic Education \\
\hline $\begin{array}{l}\text { Whole School } \\
\text { Development }\end{array}$ & DFID & $1988-2005$ & UK£50 million & $\begin{array}{l}\text { Support for } 2 \text { pilot } \\
\text { schools in each } \\
\text { district for the } \\
\text { Construction of } 125 \\
\text { classroom blocks }\end{array}$ \\
\hline $\begin{array}{l}\text { Basic Education } \\
\text { Sector Improvement } \\
\text { Programme }\end{array}$ & $\begin{array}{l}\text { IDA } \\
\text { DFID } \\
\text { USAID } \\
\text { GERMANY } \\
\text { OTHER } \\
\end{array}$ & $1996-2001$ & $\begin{array}{l}111.04 \\
\text { UK£50 million } \\
53.0 \\
5.0 \\
25 \cdot 3\end{array}$ & Basic Education \\
\hline Micro-projects & $\begin{array}{l}\text { European } \\
\text { Commission }\end{array}$ & $\begin{array}{l}1990-1996 \\
1996-2000\end{array}$ & $\begin{array}{l}\text { ECU } 14.1 \\
\text { million } \\
\text { ECU } 9 \text { million }\end{array}$ & $\begin{array}{l}\text { Construction of } \\
\text { Classroom Blocks }\end{array}$ \\
\hline $\begin{array}{l}\text { Primary Education } \\
\text { Project }\end{array}$ & USAID & 1990-1995 & 35.0 & Basıc Education \\
\hline
\end{tabular}




\begin{tabular}{|l|l|l|l|l|}
\hline $\begin{array}{l}\text { Quality } \\
\text { Improvements }\end{array}$ & USAID & $1997-2004$ & 53 & $\begin{array}{l}\text { For School } \\
\text { Improvements }\end{array}$ \\
\hline
\end{tabular}

Source: Pealore (2007); Thompson and Casely-Hayford (2007:14).

Overall, funding from external donor agencies has played a significant role in funding basic education in Ghana since the 1987 Reform Programme and has contributed to a significant growth in total education spending (Ayamdoo and Ayine, 2002; Thompson and Casely-Hayford, 2007). For instance, Ayamdoo and Ayine (2002) indicate that external donor support to the education sector since the start of the reform programme was approximately US\$400 million. Similarly, Thompson and Casely-Hayford (2007) estimated that the total value of overall external donor support to the education sector from 19862002 at US $\$ 588.3$ million. Under the Multi-Donor Budget Support (MDBS) system, total external donor support to education in terms of Credits and Grants from 2003-2005 was US\$200.9 million (World Bank, 2004; Thompson and Casely-Hayford, 2007).

External donor funding came in different forms, including loans, grants, credits and technical assistance and can be broadly grouped under three priority areas in terms of disbursement (Action Aid, 2000; Ayamdoo \& Ayine, 2002; World Bank, 2004; Thompson \& Casely-Hayford, 2007). These include infrastructural provision (the provision of classroom buildings, furniture, and teaching and learning materials), teacher training and development, and capacity building of educational administrators or managers, especially within the Ministry of Education and the Ghana Education Service (Mettle-Nunoo \& Hilditch 2000; Oduro, 2000; World Bank, 2004).

The World Bank (2004: 31) summed up the overall impact of external donor contributions on educational attainment and achievement in Ghana following the reform programme thus:

Both educational attainment and achievement have risen in Ghana over the past 15 years. The enrolment rate has risen and dropouts reduced, so that completion has risen from 60 to 73 percent. The gender gap in primary enrolments has been virtually eliminated and the gap in enrolments between children from poor and non-poor households narrowed. At the same time, test scores have improved. Children completing JSS today with nine years of basic education perform better in the Maths and English tests than did children leaving middle school after ten years of schooling in the 1980s.

The World Bank has, however, acknowledged that despite this progress, there remain challenges in the basic education sector, including some schools, most typically in poor rural areas, in which conditions, while improved, remain poor (World Bank 2004; 2007). These challenges within the basic education sector have been are highlighted below. 


\section{Remaining Challenges of the Education System}

\section{Managerial Inefficiency}

The Ministry of Education and its affiliated agencies, such as the Ghana Education Service and its division on Basic Education, with managerial responsibilities, appear to lack efficient personnel to manage the sector effectively. The Ministry itself acknowledged this shortcoming in its 2007 Preliminary Sector Performance Report: "Availability of resources is a necessary but not sufficient condition to achieve the objectives of the ESP or reforms. Clarity of policy direction, timely release of funds, managerial efficiency and quality of spending will play a key role (MOESS 2007:84)."

This conclusion emanated from a comparative analysis of the percentage of GDP spent on education and outcomes in education delivery between Ghana, Madagascar, Uganda and Kenya conducted by the Policy Research, Monitoring and Evaluation Unit of the Ministry. The research compared actual expenditure as a percentage of GDP, Primary School National Enrolment Rate, Gender Parity Index, General Enrolment Rate and Primary Completion Rate of Ghana in 2007 with those of South Africa, Kenya, Uganda and Madagascar. The results revealed that, although Ghana spends $6 \%$ of GDP compared to $4 \%$ and 3.3\% by Uganda and Madagascar respectively, Madagascar and Uganda achieved higher figures in almost all the above indicators. The study, therefore, concluded that, although financial availability is necessary for educational development, it is not a sufficient condition in this regard (MOESS, 2007).

Managerial inefficiency appears to have contributed to various challenges within the sector, including poor resource utilisation and general management. For instance, the Evaluation Team of the Pilot Programme Scheme observed in 2006 that only a quarter of the project sum of US\$40 million was disbursed by the Ghana Education Service (GES), leaving US\$30 million, despite the fact that Deprived Districts had submitted work plans to the GES for resources (MOESS, 2007). The Ministry argued that the problem was a result of 'off-budget' support arising from uncoordinated projects and inputs from donor agencies, non-governmental organisations and the private sector, which made planning and the efficient use of resources difficult (Ayamdoo \& Ayine, 2002).

This instance and several other ones were a manifestation of the level of inefficiency in managerial practices within the Ministry of Education and the Ghana Education Service (Ayamdoo \& Ayine, 2002). According to a respondent from the Ministry in this study, managerial inefficiency is due to resource constraints, which make planning and its effective execution difficult. Reacting to managerial challenges within the Ghana Education Service, a respondent from the service argued that such challenges exist, especially in deprived districts, where the poor state of socioeconomic development make them unattractive to professionals, including educational administrators. To tackle the problem of shortage of administrators in these areas, according to the respondent, 
teachers who lack administrative or managerial skills have often been appointed to perform managerial duties, resulting in such administrative lapses.

Managerial inefficiency may also account for the difficulties in teacher deployment within the basic education sector to the extent that, while some areas of the country have excess teachers (mostly urban areas), other areas (mostly rural) remain understaffed (MOESS, 2007). Urban areas often have various economic and social amenities that attract teachers. Apart from getting access to various social amenities, teachers or their families also engage in economic activities for extra income to augment their earnings. Since such amenities are lacking in deprived areas of the country, only committed teachers often accept postings to those areas.

\section{Ineffective Sector Co-ordination}

Education sector co-ordination relates to the need to oversee stakeholder activities, including donor agencies, non-governmental organisations and private providers, within the sector. The Ministry of Education is legally responsible for such co-ordination. Until 2003, when the Ministry initiated the Education Strategic Plan to co-ordinate stakeholders' activities within the sector, the activities of donor agencies and nongovernmental organisations in the sector were ad hoc (Sawyerr, 1997; ESP, 2003; CaselyHayford et al.; 2007). Officials of the Ministry and the Ghana Education Service were frequently engaged in unplanned and uncoordinated workshops and meetings with such stakeholders to the detriment of their core duties (Mettle-Nunoo \& Hilditch 2000; Ayamdoo \& Ayine, 2002).

A development consultant interviewed during the field work for this analysis used the involvement of fifteen donor agencies within the basic education sector alone to illustrate the problems that could result from poor co-ordination. The result was a fragmentation of donor projects, as each donor agency carved out its own corner of the education sector for the implementation of their programmes. The failure to pool together resources and efforts meant that donor-piloted projects could not be scaled up to maximise efficiency and impact (Mettle-Nunoo \& Hilditch, 2000; Ayamdoo \& Ayine, 2002). It was in an attempt to improve the coordination function of the Ministry that was introduced under the Education Strategy Plan in 2003 to harmonise the activities of all stakeholders within the basic education sector (ESP, 2003; also see Table 1). In line with this, donor agencies proposed the Multi-Donor Budget Support system as part of the Ghana Poverty Reduction Strategy and the Paris Declaration process (GPRS I and II 2002/4).

\section{Supervision of Public Schools}

The supervision of teachers is another challenge in the public basic education sector in Ghana and has often been cited as a key reason for the poor quality of teaching and learning outcomes in public schools (Mettle-Nunoo \& Hilditch, 20oo; Addae-Mensah, 
2000). While some progress has been made in this regard (World Bank, 2004), monitoring remains a challenge in public basic schools.

Respondents interviewed for this study pointed to the problem and attributed it to the lack of funding and weak administrative structures within the Ghana Education Service. A civil society respondent, for instance, attributed the problem to poor remuneration for circuit supervisors and logistical constraints. He said the supervisors lack adequate resources, including means of transport, to operate effectively. Circuit supervisors mostly use motorbikes to get around. According to the respondent, supervisors who are within five years of retirement are not qualified to have motorbikes because their cost is spread over 5 to 10 years, which is deducted at source from their salaries. He added that supervisors who use their own money to fuel their bikes due to delays in receiving allocations from the Ghana Education Service find it difficult to get reimbursed. The respondent also attributed poor supervision to negative attitudes. A respondent said that the long-serving head teachers were mostly promoted as supervisors were unable to supervise their former colleagues effectively due to familiarity. In order to address the challenges of this nature, the 2007 Education Reforms recommended that the Inspectorate Division of the Ghana Education Service be separated from the latter to make it independent (MOESS, 2008; see Table 1).

Another civil society respondent attributed poor supervision of public basic schools to weak administrative structures within the Ghana Education Service. The respondent argued that the administrative structures within the sector are weakened by many levels of authority. For instance, when a District Director sanctions a teacher, the sanction has to be reviewed by the Director-General of the service, who may take a counter action that may demoralise the former.

\section{Poor Motivation and Teacher Commitment}

Poor teacher motivation has also been identified as one of the reasons for poor teaching and learning outcomes in public basic schools. Low pay and discrepancies in remuneration are common problems for public sector workers generally in Ghana, which the government has been trying to resolve over the years. The latest attempt was the introduction of the Single Spine Salary Structure, a scheme that seeks to reward workers with similar qualifications in the public sector with equal remuneration. Teachers have often argued that the conditions under which they work, such as office accommodation, residential accommodation, encouragement from the public, among others, are appalling, especially when compared with those of other public sector workers. A civil society respondent, for instance, argued that, although trained teachers and nurses spend the same number of years under training, the remuneration for nurses in equivalent categories is higher than that of trained teachers. Poor teacher motivation in turn contributes to a lack of commitment with teachers leaving teaching for other sectors that offer better service conditions (See The Daily Graphic, 2008-06-16). 
All the respondents in this study agreed that poor teacher motivation is a challenge in public basic schools. A government respondent argued that the phenomenon is most prevalent in remote or deprived areas of the country partly because of the poor state of the economic and social infrastructure in those areas. A civil society respondent also argued that poor teacher motivation contributes to the difficulty in providing the required number of teachers for public schools despite the increase in trained teachers. Mettle-Nunoo and Hilditch (2000) indicate that one of DfID's interests in public sector basic education stemmed from the conviction that a third of newly trained teachers do not enter education, although one respondent argued that the number was exaggerated. Although teacher trainees are bonded to work in public schools for five years after completing their training, the Ghana Education Service and those District Assemblies that sponsor such trainees are unable to enforce the bond because institutions fail to keep track of the trainees.

Teacher attrition rates have also been attributed to the admission of Senior High School graduates into training colleges, who, because they are unable to secure admission to universities, often want to take advantage of teacher trainee allowances or use the training colleges as a stepping-stone to university (Kadingdi, 2004). Therefore, their primary motive is not to become teachers but as stepping stones for seeking the first alternative opportunity. However, a government respondent disputed this claim by arguing that anybody who qualifies to enter a training college is more than $70 \%$ qualified to enter university. In addition, if anybody goes through the training college system without teaching for three or more years and instead goes to the university, they will not get study leave with pay. The respondent added:

The only situation where one may do this is when they want to use the period in the training college to improve their Senior Secondary School Certificate Examinations results, if they could not enter the university straightaway with the result (Interview transcript).

Another government respondent supported this view, adding that some people now prefer teacher-training colleges to university because of ready and greater job security, as all newly trained teachers are posted straightaway to the classroom.

\section{Disparities within the Basic Education Sector}

Another major challenge, which remains within the Ghanaian basic education sector, despite numerous efforts to resolve it, relates to inequalities in provision between rich and deprived areas, between boys and girls, and between public and private schools.

While northern Ghana (Northern, Upper East and West regions) is generally deprived compared to the South (Rimmer, 1992), deprived areas exist throughout the country, just as some economically endowed communities exist in the North (urban centres). The deprivation of the North, particularly in terms of educational opportunities, dates back to the colonial era when that part of the country was regarded as a 'labour reservoir' for 
the mining and cocoa growing areas of the South (Bening, 1990). Despite numerous efforts to close the gap, there persists about eighty-five years of educational development gap between the poorer North and the more developed South. For instance, in 2001, the first Senior High School to be opened in the Northern Region (Tamale Senior High School 1951) celebrated its fortieth anniversary; the first Senior High School in the south (Mfantsipim Senior High School 1876) celebrated its $125^{\text {th }}$ anniversary.

Due to its deprived nature, northern Ghana has often lagged behind southern Ghana in all national measures of educational performance, including access to and participation in education, quality of education and the distribution of educational resources such as professional teachers. The educational deprivation of the Northern Region in particular might have been compounded further by the fact that it has a dominant Muslim population. Until recently, Muslim parents appeared to frown upon Western-style formal education because it was pioneered by Christian Missionaries and hence, it has been feared that pupils from a Muslim background might be converted to Christianity (Ayamdoo \& Ayine, 2002). The two other regions in the North (Upper East and Upper West) had earlier encounters with Christianity and, therefore, have dominant Christian populations who embrace Western-style education much earlier.

Another inequality in the education sector in Ghana is between male and female access. See Table 4 below.

Table 4: Girls' Participation in Basic Education, 2003/4 to 2006/7

\begin{tabular}{|l|l|l|l|l|l|l|l|l|l|l|l|l|}
\hline YEAR & \multicolumn{3}{|c|}{$\mathbf{2 0 0 3 / 0 4}$} & \multicolumn{3}{|c|}{$\mathbf{2 0 0 4 / 0 5}$} & \multicolumn{2}{|c|}{$\mathbf{2 0 0 5 / 0 6}$} & \multicolumn{3}{|c|}{$\mathbf{2 0 0 6 / 0 7}$} \\
\hline Indicator & $\begin{array}{l}\text { PFE } \\
\%\end{array}$ & $\begin{array}{l}\text { GPI } \\
\%\end{array}$ & $\begin{array}{l}\text { CR } \\
\%\end{array}$ & $\begin{array}{l}\text { PFE } \\
\%\end{array}$ & $\begin{array}{l}\text { GPI } \\
\%\end{array}$ & $\begin{array}{l}\text { CR } \\
\%\end{array}$ & $\begin{array}{l}\text { PFE } \\
\%\end{array}$ & $\begin{array}{l}\text { GPI } \\
\%\end{array}$ & $\begin{array}{l}\text { CR } \\
\%\end{array}$ & $\begin{array}{l}\text { PFE } \\
\%\end{array}$ & $\begin{array}{l}\text { GPI } \\
\%\end{array}$ & $\begin{array}{l}\text { CR } \\
\%\end{array}$ \\
\hline KG & - & 0.98 & 42.1 & & 0.98 & 48.0 & - & 1.03 & 50.4 & & 0.99 & 79.7 \\
\hline Primary & 83.1 & 0.93 & 77.9 & 84.40 & 0.93 & 78.7 & - & 0.95 & 75.6 & - & 0.96 & 85.4 \\
\hline JSS & - & 0.88 & 58.0 & & 0.88 & 60.0 & & 0.93 & 77.9 & - & 0.91 & 65.0 \\
\hline
\end{tabular}

Source: Ministry of Education, Science and Sports 2005 and 2007

Note: GPI - Gender Parity Index; CR - Completion Rate; PFE - Percentage of Female Enrolment

There has been a general lukewarm attitude towards girls' education in the country, although the situation could be changing due to intensive affirmative action by government, non-governmental organisations and civil society institutions. The reasons for poor girls' participation are varied and include cultural and religious, as well as problems relating to fertility, abuse and ignorance (MOESS, 2007; Asare, 2009; Okrah, 2008). For cultural and religious reasons, for instance, female children are often married at school age. Some people also hold the view that female education is less beneficial to the family since they tend to perform poorly in school especially in rural communities (Oduro, 2000). The Girls' Education Unit of the Ministry of Education has embarked on a range of 
activities, including community mobilisation and sensitisation to create awareness on the importance of girls' education (MOESS, 2008).

The Ghanaian government's policy on girl child education has been to provide equal access at all levels in line with the Millennium Development Goal on gender parity target of 1:1 by 2015. With a primary education gender parity of $0.93 \%$ in 2005 , Ghana slightly missed the target but has since made progress in that regard (DFID, 2009; Asare, 2009; UNICEF, 2009; MOESS, 2008; also see Table 4). Countries that met the target in Africa in 2005 included the Gambia, Gabon, Lesotho, Libya, Malawi, Mauritius, Mauritania, Namibia, Rwanda, Seychelles and Uganda (ECA/AUC, 2008).

\section{Conclusions and Recommendations}

This paper has considered efforts by the Ghanaian government and its development partners (external donor agencies) to tackle Ghana's basic education sector challenges, following the country's economic and political downturns of the mid 196os up to the early 1980s. The implementation of the 1987 Education Reform Programme, which was introduced by the government to address these challenges, had led to the closer involvement of multilateral and bilateral donors in Ghana's basic education sector.

The analysis has shown that external donor support has boosted spending on education in Ghana. For instance, the support provided by the World Bank in collaboration with the IMF towards strengthening the Ghanaian economy, led to increased education spending. These were further expanded by the creation of the Ghana Education Trust Fund (GETFund) and accruals from internally generated funds within the education sector. Taken together, these increased sources resulted in increased spending. The improvement in the economy enabled the Ghanaian government to increase its own spending on basic education relative to external donor contributions since the mid-1980s. Notwithstanding the diminution of external donor funding over the period, their support played an important role in improving educational infrastructure, the quality of teaching and learning, as well as increasing the participation of underserved groups, such as females and deprived communities.

Despite the valuable contribution of donor agencies, many of Ghana's basic education sector challenges, including ineffective sector management and co-ordination, ineffective supervision of public basic schools, poor teacher motivation and commitment, and the disparity in the distribution of educational resources and access, still remain. Access has been expanded but there still exist underserved groups, particularly girls and economically deprived communities.

The paper has demonstrated that Ghana's basic education system requires much more effective strategic management since the absence of that has contributed to the poor utilisation of scarce financial and human resources. Ineffective management has contributed to poor trained teacher deployment to the extent that some areas have too 
many, while other areas do not have enough. Thus, steps need to be taken to encourage more teachers to accept postings to the less attractive but most needy or deprived areas.

While many of the challenges, including ineffective management and the disparities within the education sector, can be blamed on the Ghanaian government and its implementing agencies, development partners, especially in the 1980s and the 1990s, also played a role in that regard. For instance, some donor agencies did not subscribe to the Multi-Donor Budget Support system, which attempted to coordinate all initiatives in the basic education sector and instead preferred to work alone. There is, therefore, the need for a commitment by the Ghanaian Government and its development partners to stick to strategies that aim at coordinating activities within the basic education sector to ensure the maximum utilisation of resources.

\section{References}

Abdallah, A. (1986). 'Speech on the State of the Education System in Ghana: Address to the Nation.' Accra.

Addae-Mensah, I. (2000). Education in Ghana: A tool for Social Mobility or Social Stratification? Accra: The J. B. Danquah Memorial Lectures.

Ahadzie, W. (2000). 'Ghana's Education Reform: Equalising Opportunities or Marginalising the Poor? Social Policy: Journal of the Centre for Social Policy Studies 1 (2), 18-33.Legon: University of Ghana.

Allsop, T., Attah, R., Cammack, T., Woods, E. (2009). Mid-Term Evaluation of the EFA Fast Track Initiative: Country Case Study. Ghana: DRAFT [online]. Available: http:// www.cambed.com/fasttrackinitiative/download/FTI_Ghana Report/ [Accessed 2010-05-06].

Asare K. (2009). Making Schools Safe for Girls: The Impact of School Infrastructure on Girls' Access to Quality Basic Education in Ghana. Accra: NECC.

Ayamdoo, C. and Ayine, D. (2002). Worsening the Woes: The Role of Donors in Education. Tamale: Integrated Social Development Centre.

Bening, R. B. (1990). A History of Education in Northern Ghana 1907 - 1976. Accra: Ghana Universities Press.

Casely-Hayford, L., Palmer, R., Ayamdoo, C. and Thompson, N. M. (2007). [online] Aid and Donor Partnerships' in Ghana's Education Sector, 1987-2007: A Critical Review of the Literature and Progress. Accra: RECOUP. Available from http://www.web.net/ afc/ downloads/Aid\%20\&\%20Partnership/1\%20 [Accessed: 2010-05-20]. 
DFID (2010). Working to reduce poverty in Ghana, Education [online].Available from http:// www.dfid.gov.uk/Where-we-work/Africa-West [Accessed 2010-04-20].

Dzobo, N. K. (1974). The Report of the Education Review Committee: The New Structure and Content of Education for Ghana. Accra: Ministry of Education.

ECA/AUC (2008). Assessing Progress in Africa towards the Millennium

Development Goals Report 2008. Economic Commission for Africa and African Union commission.

Fobih, D., K. Akyeampong, K. and A. Koomson (1999). Ghana Primary School Development Project: Final Evaluation of Project Performance. Accra: Ministry of Education.

Government of Ghana/National Development Planning Commission (2003). Ghana Poverty Reduction Strategy (GPRS I): An Agenda for Growth and Prosperity: Analysis and Policy Statements Vol. 1. Accra: National Development Planning Commission.

Ghana Government/National Development Planning Commission (2005). Growth and Poverty Reduction Strategy (GPRS II). Accra: National Development Planning Commission.

Kadingdi, S. (2004).'Policy Initiatives for Change and Innovation in Basic Education Programmes in Ghana.' Educate ..., Vol. 4, No. 2.

Konadu, A. N. (2008). 'Teachers Abandon Classrooms For Other Professions.' The Daily Graphic 16 June, 1.

Mettle-Nunoo, R. and Hilditch, L. (2000). A Report on Donor Participation in the Education Sector in Ghana. Accra: Action Aid.

Ministry of Education, Science and Sports (MOESS)(2005). Preliminary Education Sector Performance Report. Accra: Planning Unit.

Ministry of Education, Science and Sports (2007). Preliminary Education Sector Performance Report. Accra: Planning Unit.

Ministry of Education, Science and Sports (2008). Preliminary Education Sector Performance Report. Accra: Planning Unit.

Ministry of Education (MoE) (1987). Ghana's Education System. Accra: Ministry of Education Publication.

Ministry of Education (2003). Education Strategic Plan: Vol. 1: Policies, Targets Strategies. Accra: Ministry of Education. 
Oduro, A. D. (2000). Basic Education in Ghana in the Post-Reform Period [online]. Accra: Centre for Policy Analysis. Available from http://www.cepa.org.gh/researchpapers [Accessed: 2007-03-09].

Okrah, E. (2008). Good Practices: Fighting the Sexual Exploitation of Children and Adolescents in Ghana. UNICEF [online]. Available from www.unicef.org/protection/ files/ [Accessed 2010-05-11].

Pealore, D. (2007). Country-Led Evaluation: Ghana's Experience Evaluation in District Capacity Building Programme in Education Sector [online]. IDEAS. Available from http://www.ideas-int.org/ [Access 2010-04-22].

Sawyerr, H. (1997). Country-Led Aid Coordination in Ghana. Paris: ADEA.

World Bank (2004). Books, Buildings, and Learning Outcomes: An Impact Evaluation of World Bank Support To Basic Education in Ghana[online]. Washington, D. C: World Bank, www.worldbank.org.oed [Accessed: 2009-02-09].

UNICEF (2009). Briefing Papers: Social protection to tackle child poverty in Ghana [online]. Available from http://www.unicef.org/wcaro/wcaro [Accessed 2010-04-24] 